\title{
New Species of Glassfrog, Genus Hyalinobatrachium (Anura: Centrolenidae), for the Brazilian Amazon Revealed by Mitochondrial DNA and Morphology
}

\author{
Elciomar Araújo de Oliveira*1, Emil José Hernández-Ruz ${ }^{2}$ \\ ${ }^{1}$ Programa de Pós graduação em Biodiversidade e Biotecnologia da Rede Bionorte, Universidade \\ Federal do Amazonas, Av. Gen. Rodrigo Octávio Jordão Ramos, Manaus, AM, Brazil. \\ ${ }^{2}$ Programa de Pós-Graduação em Biodiversidade e Conservação, Faculdade de Ciências Biológicas, \\ Campus Universitário de Altamira, Universidade Federal do Pará, Rua Coronel José Porfírio, 2515, \\ São Sebastião, Altamira, Pará, Brazil.
}

\begin{abstract}
This work describes a new species of Hyalinobatrachium for the Brazilian Amazon, in the Tapajós biogeographic region, between the Xingu and Tapajós rivers, two large tributaries of the Amazon River. The new species distinguishes itself from all congeneric species by morphological data and genetic distance based on the $16 \mathrm{~S}$ mitochondrial gene fragment. The new species differentiates from its congeneric ones mainly by the absence of the nuptial excrescence, the white disc I finger and the peritoneum of the yellow gallbladder. Geneticaly for H. munozorum, $H$. fleischmanni and H. carlesvilai and morphologically similar to H. mondolfii. It will be the sixth one registered for Brazil, occurring in the Tapajós biogeographic region.
\end{abstract}

Keyword: Amphibia, Xingu, Hyalinobatrachium mondolfii, Hyalinobatrachium munozorum, Hyalinobatrachium muiraquitan sp. nov.

Abbreviations: snout-vent length (SVL); head length (HL); head width (HW); interorbital distance (IOD); eye length (EL); upper eyelid width (EW); eye to snout tip distance (ES); width of disc on Finger III (DW); femur length (FEL); tibia length (TL); foot length (FL).

\section{INTRODUCTION}

Currently 30 species of Hyalinobatrachyum Ruiz-Carranza and Lynch 1991, are described [1], distributed in tropical Central America, tropical Andes, the Cordillera of the Coast of Venezuela, Tobago, the Amazon Basin and the Shield of the Guianas [2]. Only five of these are registered for Brazil [3]: Hyalinobatrachium carlesvilai Castroviejo-Fisher, Padial, Chaparro, Aguayo-Vedia and De la Riva, 2009, Hyalinobatrachium cappellei Van Lidth de Jeude, 1904, Hyalinobatrachium iaspidiense (Ayarzagüena, 1992), Hyalinobatrachium mondolfii Señaris and Ayarzagüena, 2001, and Hyalinonatrachium munozorum (Lynch and Duellman, 1973). In the state of Pará H. iaspidiense [1] and $H$. mondolfii [4] were recorded.

The taxonomy of glass frogs, as they are popularly known, is still quite confusing $[5 ; 6 ; 7 ; 8]$, making it difficult to exactly assess the diversity of species and their distributions, even with the taxonomy works carried out in the Ecuador [9], Venezuela [10], Guiana Shield [8] and Guiana [11]. Due to the morphological similarities found within the genus [10;12], these species pose a problem for conservation measures, because distinct species may be masked because of phenotypic conservation, presenting a restricted distribution. A solution to this taxonomic problem may be applying integrative taxonomy, which takes into account several lines of evidence and criteria to identify divergent lineages $[13 ; 14 ; 15 ; 16 ; 17]$, assuming that species are segments of lineages of separately evolving metapopulations $[18 ; 19 ; 20 ; 21 ; 22]$.

Based on morphological and molecular data, we describe a new species of Hyalinobatrachyum for Brazil, morphologically similar to $H$. mondolfii. It will be the sixth one registered for the country, occurring in the Tapajós biogeographic region, which is considered an area of important endemism for conservation and studies on the origin of the Amazonian biota [23; 24]. The new species differentiates from its congeneric ones mainly by the absence of the nuptial excrescence, the white disc I finger and the peritoneum of the yellow gallbladder. 


\section{MATERIAL AND METHODS}

\subsection{Nomenclature}

This study is based on literature data and analyzes of specimens collected in the field with ecological data information. The specimens used in this study were fixed in $10 \%$ formalin and preserved in $70 \%$ alcohol. The specimens and data examined are listed in Additional Information 2. The characters quoted here are for adults only. Ontogenetic status was determined by the presence of secondary sexual characters (vocal sac and nuptial callus), as well as field data (vocalization). Two couples were collected in amplexo, with posterior spawning in plastic bags. The credit for the photos goes to Leandro de Souza Mello. We follow [2;25] for the supra-specific classification. The specimens were collected with the authorization for collection and transportation 32401 from SISBIO, Brazil.

\subsection{Morphology}

For terminology and definitions of morphological characters and coloration, we follow $[2 ; 3 ; 5 ; 6 ; 8$; 10; ]. The terminology of basal networks follows [26]. Description of the nuptial excrement (bridal callus) and prepolical thorn follows [27], with additions of [2]. Coloring characteristics were observed in living individuals, color photographs and literature data [2;6;10;13].

The species described in this work distinguishes itself from all other species mainly in comparisons of qualitative morphological characters and molecular synapomorphies. Due to the difficulty in accessing materials stored in zoological collections, we have studied and compared the characters listed and described in detail by $[8 ; 28]$ for the species of Hyalinobatrachium, drawing comparisons with the new species.

The morphometric measurements were made with the help of digital caliper $0.01 \mathrm{~mm}$. Literature data from the holotype of Hyalinobatrachium mondolfii [28] was used. Abbreviations for measurements are as follows: snout-vent length (internarial tip of the snout to the posterior edge of cloacal opening, SVL); head length (posterior edge of the jaw articulation to the internarial tip of the snout, HL); head width (greatest width of head, at the posterior edge of the jaw articulation, HW); interorbital distance ( distance between the inner margins of the orbits, IOD); eye length (horizontal diameter, EL); upper eyelid width (greatest transverse width, EW); eye to snout tip distance ( from tip of snout to anterior margin of eye, ES); width of disc on Finger III (DW); femur length (distance from the middle of the cloacal slit to the femur-tibia articulation, FEL); tibia length (from the femur-tibia to the tibia-heel articulation, TL); foot length (distance from proximal margin of outer metatarsal tubercle to tip of Toe IV, FL).

We consider that a taxon presented divergence in morphology when displaying at least one fixed (qualitative) character, no overlap (quantitative) or a single combination separating this from other taxa, according to [8]. The purpose of this assumption is that fixed differences in morphology are a strong indication of reduced or absent gene flow [29], evidence of independent lineages.

\subsection{Molecular Analysis}

Total genomic DNA was extracted from two specimens of Hyalinobatrachium aff. mondolfii of Brazil. Additionally, sequences from $H$. mondolfii available in the GenBank were employed, as well as other species of the genus (Table 1) using the pheneno-chloroform protocol [30]. A fragment of the 16S DNAr gene was amplified via PCR using the primers 16Saf and 16Sbr [31]. Amplification was performed under the following conditions: $60 \mathrm{~s}$ at $92^{\circ} \mathrm{C}$ followed by 35 cycles of $92^{\circ} \mathrm{C}(60 \mathrm{~s}), 50^{\circ} \mathrm{C}$ $(50 \mathrm{~s})$ and $72^{\circ} \mathrm{C}(1.5 \mathrm{~min})$. The final volume of the PCR reaction was $12 \mu \mathrm{L}$ and it contained $4.4 \mu \mathrm{L}$ of $\mathrm{ddH}_{2} \mathrm{O}, 1.5 \mu \mathrm{L}$ of $25 \mathrm{mM} \mathrm{MgCl}{ }_{2}, 1.25 \mu \mathrm{L}$ of $10 \mathrm{mM}$ dNTPs $(2.5 \mathrm{mM}$ each dNTP), $1.25 \mu \mathrm{L}$ of buffer $10 \mathrm{x}\left(75 \mathrm{mM}\right.$ Tris $\left.\mathrm{HCl}, 50 \mathrm{mM} \mathrm{KCl}, 20 \mathrm{mM}\left(\mathrm{NH}_{4}\right)_{2} \mathrm{SO}_{4}\right), 1 \mu \mathrm{L}$ of each primer $(2 \mu \mathrm{M}), 0.3 \mu \mathrm{L}$ of $1 \mathrm{U}$ Taq DNA Polymerase and $1 \mu \mathrm{L}$ of DNA $(30-50 \mathrm{ng} / \mu \mathrm{L})$.

The sequencing reaction was performed according to the manufacturer's recommendations for the sequencing mix ABI BigDye Terminator, using the 16Saf primer at an annealing temperature of $50^{\circ} \mathrm{C}$. The sequencing reactions were precipitated using the standard protocol of EDTA/Ethanol, resuspended with $10 \mu \mathrm{L}$ of deionized formamide (ABI) and sequenced on the automatic sequencer $\mathrm{ABI}$ 3130xl (Applied Biosystems).

The sequences were aligned using the Clustal W algorithm [32] Implemented in BioEdit software 7.2 [33]. The evolutionary molecular model GTR $+\mathrm{G}$ was chosen through the software Jmodel Test [34]. The tree Maximum Likelihood was built in software Treefinder [35] with 20,000 replicates of bootstrap. The genetic distance pairwise uncorrected ( $p$-distance) among species was calculated in software MEGA 6.0 [36]. 
New Species of Glassfrog, Genus Hyalinobatrachium (Anura: Centrolenidae), for the Brazilian Amazon revealed by Mitochondrial DNA and Morphology

Table1. List of specimens of Hyalinobatraachium used in molecular analysis

\begin{tabular}{|c|c|c|c|}
\hline Species & $\mathrm{N}^{\mathrm{o}}$ GenBank & Locality & Status \\
\hline H. muiraquitan sp. nov. & KY310570 & Vitória do Xingu & Voucher \\
\hline H. muiraquitan sp. nov. & KY310571 & Vitória do Xingu & Voucher \\
\hline H. mondolfii & JF266569.1 & Venezuela & Voucher \\
\hline H. mondolfii & JN870870.1 & Guiana & Voucher \\
\hline H. mondolfii & GQ1420461 & Venezuela & Voucher \\
\hline H. mondolfii & EU6630501 & Venezuela & Voucher \\
\hline H. fleischmanni & KR863261.1 & Panamá & Voucher \\
\hline H. cf. munozorum & EU663034 & -------------- & ------------- \\
\hline H. duranti & EU663041.1 & $\begin{array}{l}------------ \\
\end{array}$ & Voucher \\
\hline H. ibama & EU663048.1 & ----------- & Voucher \\
\hline H. orientale & EU447289.1 & Venezuela & Voucher \\
\hline H. orocostale & EU447288.1 & Venezuela & voucher \\
\hline H. fragile & EU663046.1 & ------------ & voucher \\
\hline H. carlesvilai & KM068269.1 & ------------- & voucher \\
\hline H. carlesvilai & KM068270.1 & -------------- & voucher \\
\hline H. fleischmanni & KR863261.1 & Panamá & voucher \\
\hline H. bergeri & GQ142059.1 & -------------- & voucher \\
\hline H. talamancae & FJ784480.1 & Panamá & voucher \\
\hline Hyalinobatrachium sp. & KM068299.1 & ----------- & voucher \\
\hline H. pellucidum & GQ142065.1 & ------------- & voucher \\
\hline H. colymbiphyllum & KR863254.1 & Panamá & voucher \\
\hline H. chirripoi & KF604299.1 & Panamá & voucher \\
\hline H. aureoguttatum & EU663032.1 & -------------- & voucher \\
\hline H. valerioi & EU663057.1 & -------------- & voucher \\
\hline H. taylori & JN870873.1 & Venezuela & voucher \\
\hline H. crurifasciatum & EU663040.1 & -------------- & voucher \\
\hline H. eccentricum & EU663042.1 & $\begin{array}{l}------------ \\
\end{array}$ & voucher \\
\hline H. ignioculus & EU663049.1 & -------------- & voucher \\
\hline H. pallidum & EU663052.1 & ------------- & voucher \\
\hline H. iaspidiense & JN870867.1 & Brazil & voucher \\
\hline Cochranella revocata & EU663019.1 & |------------ & ----------- \\
\hline
\end{tabular}

Bayesian Analysis of Population Structure (BAPS) was implemented in the software BAPS 5.0 [37] to find clusters formed with the sequences obtained in this study and available in GenBank. The BAPS software uses nucleotide frequencies of the samples to infer the $\mathrm{K}$ number of different groups genetically by Bayesian analysis, allocating similar sequences in the same group. The maximum number of $\mathrm{K}$ chosen for the analysis was three, corresponding to the number of locations (Brazil, Guyana and Venezuela). The log-likelihood value of the best model was used to choose the most likely clustering configuration.

\section{Results AND Discussion}

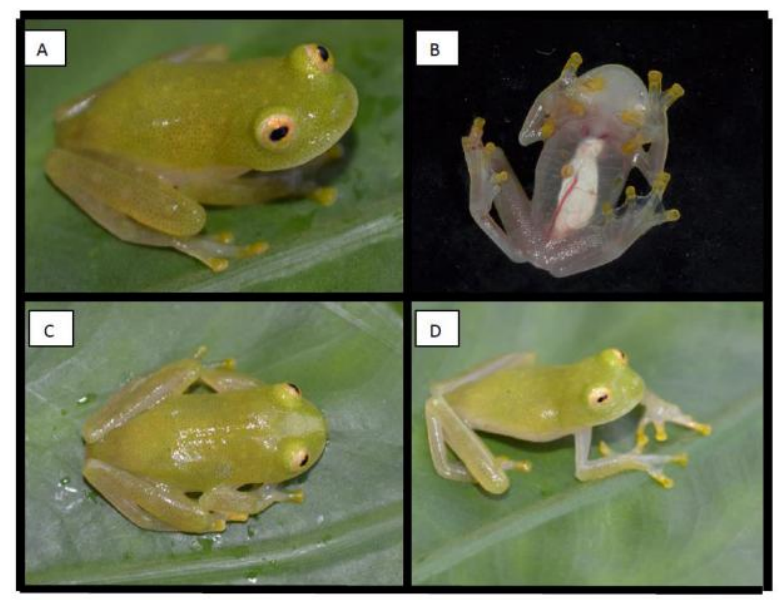

Figure1. Hyalinobatrachium muiraquitan sp. nov. In life collected at the Vitória farm in the municipality of Vitória do Xingu, Pará - Brazil. Dorsal view in A, C and D, ventral view in B. (photo: Leandro Souza de Melo). 


\subsection{Holotype (LZA 841)}

Adult male collected January 15, 2016 by Elciomar Araújo de Oliveira and Joyce Celerino de Carvalho at Vitoria farm (S: $02^{\circ} 58^{\prime \prime} 00^{\prime}$ and W $052^{\circ} 13^{\prime \prime} 00$ ) municipality of Vitória do Xingu, State of Pará, Brazil.

\subsection{Paratypes}

One adult male (LZA 842) and two adult females (LZA 843 and LZA 844) collected in the same locality of the holotype.

\subsection{Genus Hyalinobatrachium}

The new species belongs to the genus Hyalinobatrachium, as evidenced by sharing the states of the characters indicated in, [38; 39; 5]: (1) absence of humeral spines; (2) digestive tract and liver bulbs covered by white peritoneum; (3) ventral parietal peritoneum completely transparent; (4) white bones in life, green in H. mesai Barrio-Amorós and Brewer-Carias, 2008 and H. taylori (Goin, 1968); (5) dorsal coloration white or cream when in alcohol; (6) males without dorsal spines in reproductive age; (7) when present, the nuptial callus is small and restricted to the inner side of finger I of the hand of the males; (8) dentigerous process of vomer and absent vomiting teeth; (9) males usually vocalize on the underside of the leaves, and the females lay a layer of eggs in the same location; and (11) complete fusion of the tibia and fibula.

\subsection{Diagnosis}

(1) dentigerous process of vomer and absent vomerine teeth; (2) face rounded in dorsal view and truncated in side view; (3) tympanus covered by skin (4) dorsally, smooth skin or weakly shagreen in life and alcohol; (5) ventrally, granular or smooth skin, absent warts on the sewer; (6) pericardium and white hepatic peritoneum, all other peritones are transparent, yellow gallbladder peritoneum; (7) bulbous liver; (8) absent humeral spine; (9) formula of the membranes of the fingers III $2\left(0^{-}-0^{-}\right)$IV; (10) basal network on toes I $(1-1)-\left(1_{3 / 4}-1_{1 / 4}\right)$ II $\left(1_{1 / 4}-1\right)-\left(2-1_{1 / 2}\right)$ III $(2-0)-(3-0)$ IV $(3-0)-$ $\left(2-0^{-}\right) \mathrm{V}$; (11) absent nuptial excrescences, pre-polex not evident in external view; (12) finger I longer than finger II; (13) diameter of the eye thinner than the disc of hand finger III; (14) coloring in life: yellow dotted dorsum forming light green and tiny black melanophores extending through the limbs, white bones; (15) coloring in alcohol: light cream dotted with tiny black melanophores; (16) gilded iris with gray halftones near the pupil; (17) tiny black melanophores present only at the base of the IV finger and at the base of the IV and V toes. In life the discs of the fingers are all yellow, while in the feet, the disk of toe I is white, while all the others are yellow; (18) deposits of eggs on the underside of the leaves; (19) adult size between 19.2 - $19.6 \mathrm{~mm}$ in two males and 20.0-21.8 $\mathrm{mm}$ in two females; (20) nineteen molecular autapomorphs on the mitochondrial gene fragment $16 \mathrm{~S}$ (table 2).

Table2. Diagnostic characters on the $16 S$ gene fragment for Hyalinobatrachium muiraquitan sp. nov., H. mondolfii and H. munozorum.

\begin{tabular}{|c|c|c|c|}
\hline Position & H. muiraquitan sp. nov. & H. mondolfii & H. munozorum \\
\hline 20 & $\mathrm{C}$ & $\mathrm{A}$ & $\mathrm{A}$ \\
\hline 89 & $\mathrm{G}$ & $\mathrm{A}$ & A \\
\hline 108 & $\mathrm{G}$ & $\mathrm{A}$ & $\mathrm{A}$ \\
\hline 127 & $\mathrm{C}$ & $\mathrm{T}$ & $\mathrm{T}$ \\
\hline 174 & $\mathrm{C}$ & $\mathrm{T}$ & $\mathrm{T}$ \\
\hline 216 & $\mathrm{~A}$ & $\mathrm{C}$ & $\mathrm{C}$ \\
\hline 227 & $\mathrm{~T}$ & $\mathrm{~A}$ & $\mathrm{~A}$ \\
\hline 232 & $\mathrm{~T}$ & $\mathrm{~T}$ & $\mathrm{C}$ \\
\hline 238 & $\mathrm{~T}$ & $\mathrm{C}$ & $\mathrm{C}$ \\
\hline 247 & $\mathrm{~A}$ & $\mathrm{C}$ & $\mathrm{C}$ \\
\hline 249 & $\mathrm{C}$ & $\mathrm{T}$ & $\mathrm{T}$ \\
\hline 250 & $\mathrm{C}$ & $\mathrm{T}$ & $\mathrm{T}$ \\
\hline 253 & $\mathrm{~T}$ & $\mathrm{C}$ & $\mathrm{C}$ \\
\hline 359 & $\mathrm{~A}$ & $\mathrm{G}$ & $\mathrm{G}$ \\
\hline 328 & $\mathrm{C}$ & $\mathrm{A}$ & $\mathrm{A}$ \\
\hline 331 & $\mathrm{~A}$ & $\mathrm{~T}$ & $\mathrm{~T}$ \\
\hline 358 & $\mathrm{C}$ & A & A \\
\hline 377 & $\mathrm{C}$ & $\mathrm{T}$ & $\mathrm{T}$ \\
\hline 492 & $\mathrm{~T}$ & $\mathrm{C}$ & $\mathrm{C}$ \\
\hline
\end{tabular}




\subsection{Comparisons}

The comparison of the new species with the other congeneric species found in the eastern Brazilian Amazon or fleischmanni group sensu [38; 39] supports their identification based on morphology (characters of the new species in parentheses): H. mondolfii has rounded snout in lateral view (truncated), present excrescence nuptial (absent), yellow discs in all feet (white I finger disc), melanophores present only in the $\mathrm{V}$ foot (IV and $\mathrm{V}$ of the foot) and white gallbladder peritoneum (yellow); H. munozorum has a white gallbladder (yellow), absent melanophors (present), basal network present between fingers I and II (absent), rostrum rounded in side view (truncated), absent tarsal and ulnar fold (present); H. ruedai Ruiz-Carranza and Lynch, 1998 has formula basal networks of hands III $2-1_{1 / 4}$ IV (H. muiraquitan. sp. nov. III $2\left(0^{-}-0\right)$ IV), absent melanophors (present); $H$. cappellei has black dots scattered over the back (tiny yellow dots), white discs in the fingers and toes (yellow); H. iaspidiense has irregular green spots on its back in life and small black spots (light green with yellow dots and tiny black melanophores); H. orientale (Rivero, 1968) for having red heart in life and transparent pericardium (heart and white pericardium). H. fleischmani Ruiz-Carranza and Lynch, 1991 has subacuminado rostrum in dorsal view (rounded); H. ibama Ruiz-Carranza and Lynch, 1998 has weakly granular dorsal skin texture (dorsal skin texture smooth or weakly shagreen); H. esmeralda Ruiz-Carranza and Lynch, 1998 has a formula of the membranes of the fingers III $2^{+}-2^{+}$ IV (the new species has formula III $2\left(0^{-}-0^{-}\right)$IV)

\subsection{Molecular Analysis}

The population structure analysis performed by BAPS, with the species Hyalinobatrachium mondolfii and $H$. muiraquitan sp. nov. revealed a strong structuring between the populations of Brazil and Venezuela + Guyana $(\log M L=-409.7148$; probability $=100 \%$, Figure 2$)$. Based on this result and considering the phylogenetic analysis of the nominal species Hyalinobatrachium mondolfii, we observed the existence of two lineages (Figure 3). The first is composed of individuals from the Shield of Guyana and Venezuela, based on GenBank sequences. The second is composed of individuals collected in this study in the city of Vitória do Xingu, state of Pará - Brazil. The two lineages present a genetic distance of $5 \%$ and a bootstrap value of 52 supporting the branch of the new species. It can be observed that the genetic distance value is higher than the one currently used to distinguish species of anurans (>3\%), a value that has been strongly defended by several authors based on a $16 \mathrm{~S}$ mitochondrial gene fragment $[40 ; 41 ; 42 ; 43]$, while species recognized as $H$. munozorum and $H$. mondolfii present only $2 \%$ (table 3 ).

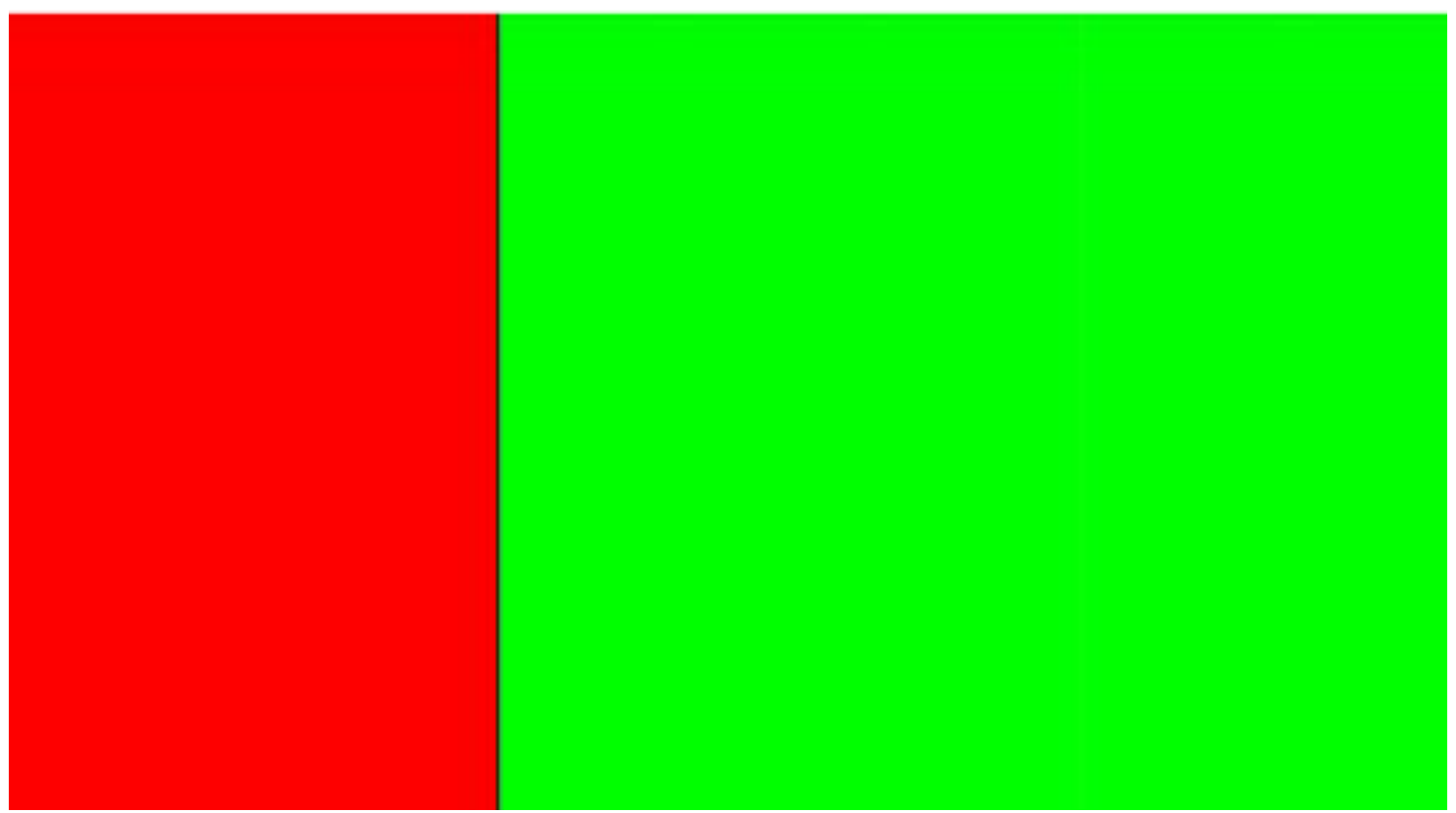

Figure2. Population structure analysis in BAPS. The colors represent the populations of the Xingu (red) and Venezuela + Guyana (green). 
Elciomar Araújo de Oliveira \& Emil José Hernández-Ruz

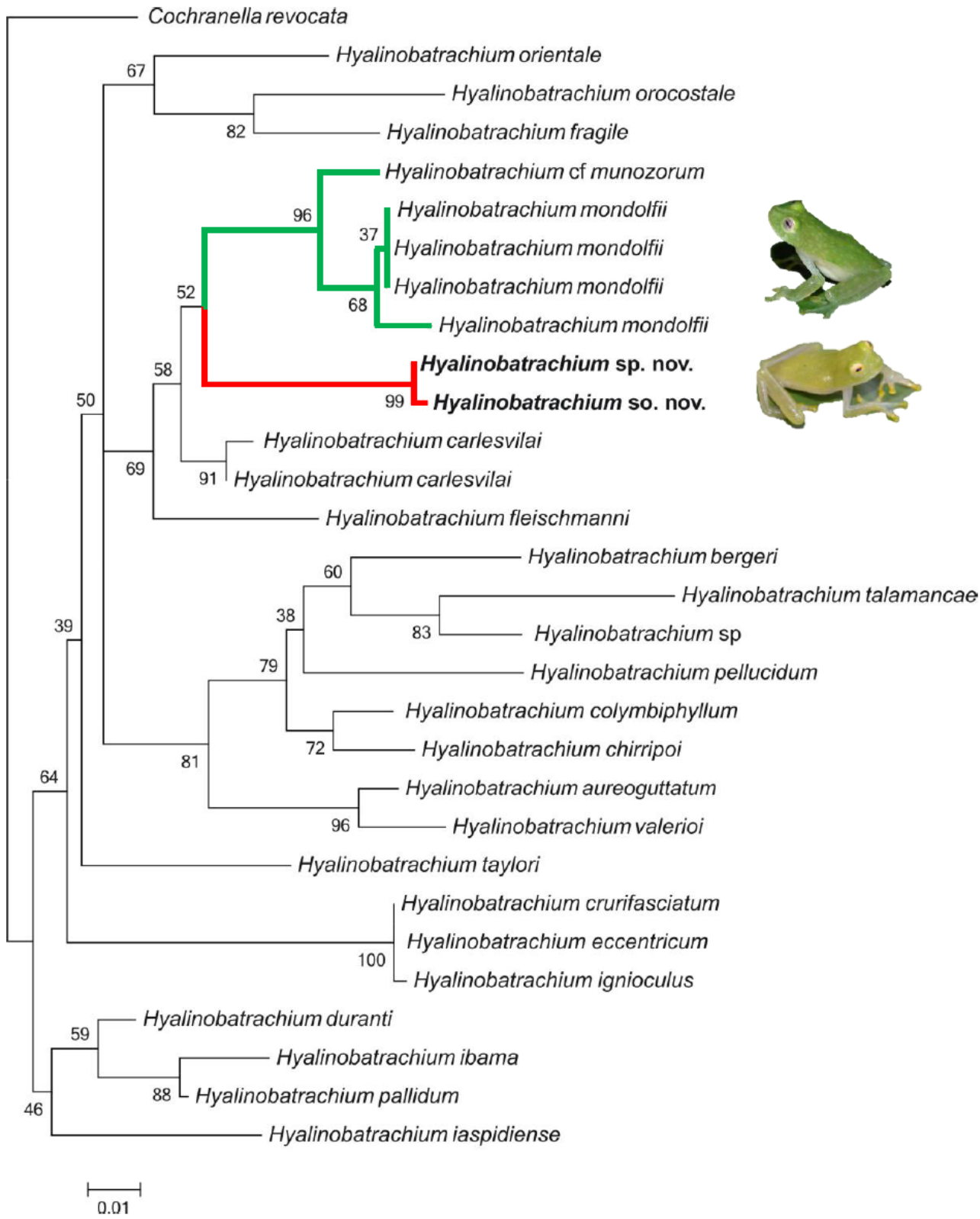

Figure3. Maximum likelihood tree based on 165 mitochondrial marker. The numbers on the nodes represent the values of boostrtap. The colors in the branches represent the biological grouping found by Bayesian analysis in the software BAPS, Xingu (red) and Venezuela + Guiana (green).

Table3. Genetic distance matrix uncorrected $(\%)$ between species of Hyalinobatrachium

\begin{tabular}{|r|r|r|r|r|r|r|r|r|r|r|r|r|r|r|r|r|r|r|r|r|r|r|r|r|r|}
\hline & 1 & 2 & 3 & 4 & 5 & 6 & 7 & 8 & 9 & 10 & 11 & 12 & 13 & 14 & 15 & 16 & 17 & 18 & 19 & 20 & 21 & 22 & 23 & 24 & 25 \\
\hline 1 & & & & & & & & & & & & & & & & & & & & & & & & & \\
\hline 2 & 0,04 & & & & & & & & & & & & & & & & & & & & & & & & \\
\hline 3 & 0,04 & 0,04 & & & & & & & & & & & & & & & & & & & & & & & \\
\hline 4 & 0,04 & 0,03 & 0,03 & & & & & & & & & & & & & & & & & & & & & & \\
\hline 5 & 0,05 & 0,02 & 0,04 & 0,03 & & & & & & & & & & & & & & & & & & & & & \\
\hline 6 & 0,06 & 0,07 & 0,06 & 0,05 & 0,06 & & & & & & & & & & & & & & & & & & & & \\
\hline 7 & 0,05 & 0,03 & 0,04 & 0,03 & 0,04 & 0,05 & & & & & & & & & & & & & & & & & & & \\
\hline 8 & 0,05 & 0,05 & 0,04 & 0,04 & 0,05 & 0,06 & 0,04 & & & & & & & & & & & & & & & & & & \\
\hline 9 & 0,06 & 0,04 & 0,05 & 0,04 & 0,04 & 0,05 & 0,02 & 0,04 & & & & & & & & & & & & & & & & & \\
\hline 10 & 0,06 & 0,05 & 0,05 & 0,04 & 0,05 & 0,06 & 0,04 & 0,04 & 0,05 & & & & & & & & & & & & & & & & \\
\hline 11 & 0,06 & 0,05 & 0,05 & 0,05 & 0,05 & 0,06 & 0,04 & 0,05 & 0,05 & 0,03 & & & & & & & & & & & & & & & \\
\hline 12 & 0,06 & 0,06 & 0,05 & 0,05 & 0,05 & 0,06 & 0,05 & 0,06 & 0,06 & 0,06 & 0,06 & & & & & & & & & & & & & & \\
\hline 13 & 0,06 & 0,05 & 0,05 & 0,05 & 0,05 & 0,06 & 0,05 & 0,06 & 0,06 & 0,06 & 0,06 & 0,00 & & & & & & & & & & & & & \\
\hline 14 & 0,06 & 0,04 & 0,04 & 0,04 & 0,04 & 0,06 & 0,02 & 0,04 & 0,01 & 0,05 & 0,05 & 0,06 & 0,05 & & & & & & & & & & & & \\
\hline 15 & 0,06 & 0,05 & 0,05 & 0,05 & 0,05 & 0,06 & 0,05 & 0,06 & 0,06 & 0,06 & 0,06 & 0,00 & 0,00 & 0,05 & & & & & & & & & & & \\
\hline 16 & 0,06 & 0,05 & 0,06 & 0,04 & 0,06 & 0,06 & 0,03 & 0,06 & 0,04 & 0,06 & 0,05 & 0,06 & 0,06 & 0,05 & 0,06 & & & & & & & & & & \\
\hline 17 & 0,06 & 0,04 & 0,05 & 0,04 & 0,05 & 0,07 & 0,03 & 0,04 & 0,04 & 0,05 & 0,05 & 0,06 & 0,05 & 0,04 & 0,05 & 0,05 & & & & & & & & & \\
\hline 18 & 0,06 & 0,05 & 0,05 & 0,05 & 0,05 & 0,03 & 0,04 & 0,05 & 0,04 & 0,05 & 0,05 & 0,06 & 0,05 & 0,05 & 0,05 & 0,05 & 0,05 & & & & & & & & \\
\hline 19 & 0,06 & 0,06 & 0,06 & 0,05 & 0,05 & 0,04 & 0,05 & 0,06 & 0,05 & 0,06 & 0,06 & 0,05 & 0,05 & 0,05 & 0,05 & 0,06 & 0,06 & 0,04 & & & & & & & \\
\hline
\end{tabular}


New Species of Glassfrog, Genus Hyalinobatrachium (Anura: Centrolenidae), for the Brazilian Amazon revealed by Mitochondrial DNA and Morphology

\begin{tabular}{|l|l|l|l|l|l|l|l|l|l|l|l|l|l|l|l|l|l|l|l|l|l|l|l|l|l|l|l|l|l|}
\hline \hline 20 & 0,06 & 0,06 & 0,06 & 0,06 & 0,06 & 0,05 & 0,05 & 0,06 & 0,05 & 0,06 & 0,07 & 0,07 & 0,06 & 0,06 & 0,06 & 0,06 & 0,06 & 0,04 & 0,04 & & & & & & \\
\hline 21 & 0,06 & 0,05 & 0,05 & 0,05 & 0,06 & 0,05 & 0,05 & 0,05 & 0,05 & 0,06 & 0,05 & 0,06 & 0,06 & 0,05 & 0,06 & 0,06 & 0,05 & 0,04 & 0,06 & 0,05 & & & & & \\
\hline 22 & 0,06 & 0,06 & 0,06 & 0,06 & 0,06 & 0,05 & 0,05 & 0,05 & 0,05 & 0,06 & 0,05 & 0,07 & 0,07 & 0,05 & 0,07 & 0,07 & 0,05 & 0,04 & 0,06 & 0,05 & 0,02 & & & & \\
\hline 23 & 0,07 & 0,06 & 0,05 & 0,05 & 0,06 & 0,04 & 0,04 & 0,05 & 0,04 & 0,06 & 0,05 & 0,06 & 0,06 & 0,04 & 0,06 & 0,05 & 0,05 & 0,02 & 0,05 & 0,04 & 0,04 & 0,05 & & & \\
\hline 24 & 0,08 & 0,07 & 0,07 & 0,06 & 0,07 & 0,03 & 0,06 & 0,06 & 0,05 & 0,07 & 0,05 & 0,07 & 0,07 & 0,06 & 0,07 & 0,07 & 0,07 & 0,05 & 0,04 & 0,06 & 0,06 & 0,06 & 0,05 & & \\
\hline 25 & 0,05 & 0,05 & 0,05 & 0,04 & 0,05 & 0,05 & 0,03 & 0,05 & 0,04 & 0,05 & 0,05 & 0,05 & 0,05 & 0,04 & 0,05 & 0,04 & 0,05 & 0,04 & 0,05 & 0,05 & 0,05 & 0,06 & 0,05 & 0,06 & \\
\hline
\end{tabular}

1) Hyalinobatrachium muiraquitan sp. nov. (Brasil); 2) H. munozorum; 3) H. fleischmanni; 4) H. carlesvilai; 5) H. mondolfii (Venezuela e Guiana); 6) Hyalinobatrachium sp.; 7) H.duranti; 8) H. orientale; 9) H. pallidum; $e$ 10) H. fragile; 11) H. orocastale; 12) H. ignioculus; 13) H. eccentricum; 14) H. ibama; 15) H. crurifasciatum; 16) H. iaspidiense; 17) H. taylori; 18) H. colymbiphyllum; 19) H. bergeri; 20) H. pellucidum; 21) H. aureoguttatum; 22) H. valerioi; 23) H. chirripoi; 24) H. talamancae and 25) Craugastor revocata.

\subsection{Description of Holotype}

Adult male with SVL $19.2 \mathrm{~mm}$; HW $39.5 \%$ of SVL; head wider than long (HW/HL = 1.2); rostrum rounded in dorsal view and truncated in side view; $\mathrm{ES} / \mathrm{EL}=1.6$ and $\mathrm{ES} / \mathrm{IOD}=2$; concave loreal region; prominent oval nostrils; depression of internarial region; canthus rostralis not evident; small eye (EL $29 \%$ of HL); undistinguished tympanic annulus, absent tympanic membrane, absent tympanic above fold, dentigerous process absent vomer; elongated and ovoid tongue, not fixed to the posterior or side of the mouth, anterior region $2 / 3$ the length of the tongue fixed to the mouth; slits on the side of the base of the tongue; external vocal sac and medium. Lean forearm, without pleats; absent humeral spine; relative length of the fingers: II < I < IV < III; wide discs of hand fingers, only the disc of finger III is truncated; FIII $55 \%$ of EL; basal network absent between fingers I-II and weak basal webbing between fingers II-III and formula of membranes of hand fingers III $2\left(0^{-}-0^{-}\right)$; subarticular rounded slightly prominent tubercle; rounded and prominent palmar tubercle, elongated and slightly evident thenar tubercle; nuptial excrescence absent on finger and fringes of fingers II, III and IV; slender hind limbs; TL 51,5\% of SVL; rounded toe discs I, II and II and truncated IV and V; small and oval internal metatarsal tubercle; almost absent external metatarsal tubercle; basal toe network I $(1-1)-\left(1_{3 / 4}-1_{1 / 4}\right)$ II $\left(1_{1 / 4}-1\right)-\left(2-1_{1 / 2}\right)$ III $(2-0)-(3-0)$ IV $(3-0)-\left(2-0^{-}\right) \mathrm{V}$. In alcohol, dorsal skin weakly shagreen, area near to the tympanum almost granular; texture of the belly smooth and granular laterally and smooth thighs; cloacal region with few folds close to the opening, absent warts.rounded tubercle and some prominent; rounded and prominent palmar tubercle, thenar.

\subsection{Coloring in Life}

Light green dorsum with yellow dots; tiny black melanophores extending through the limbs; white bones.

\subsection{Coloring in Alcohol}

Light cream, dotted with tiny black melanophores.

\subsection{Variation}

Males have smaller SVL than females (average $=29 \mathrm{~mm}$ and $31.8 \mathrm{~mm}$, respectively). Interorbital distance is smaller in males, with an average of $2.3 \mathrm{~mm}$, while in females it is $2.65 \mathrm{~mm}$. Although they were smaller, males presented a larger length of the head than the females (average $=12.7 \mathrm{~mm}$ and $9.7 \mathrm{~mm}$ respectively). All measurements are in Additional Information 1.

\subsection{Etymology}

The specific epithet "muiraquitan" refers to artifacts carved in stone (jade, greenish color) or wood, representing people or animals (frog, fish, turtle, etc.), to which the supernatural qualities of the amulet are attributed. This epithet is used for the species due to its similarity with the muiraquitan of the legends, usually represented by greenish-colored frogs.

\subsection{Natural History}

The two adult males and females were found on the margin of a stream with a strong current, in amplexus. Several males were vocalizing at a height of $40 \mathrm{~cm}$ from the soil. Spawns were found at the site, about 11 eggs in a nest of gelatin on the underside of the leaves, on top of the water.

\subsection{Distribution}

Currently the new species can be found in the municipalities of Vitória do Xingu (locality type) and near the city of Altamira, both in the state of Pará (Figure 4). 


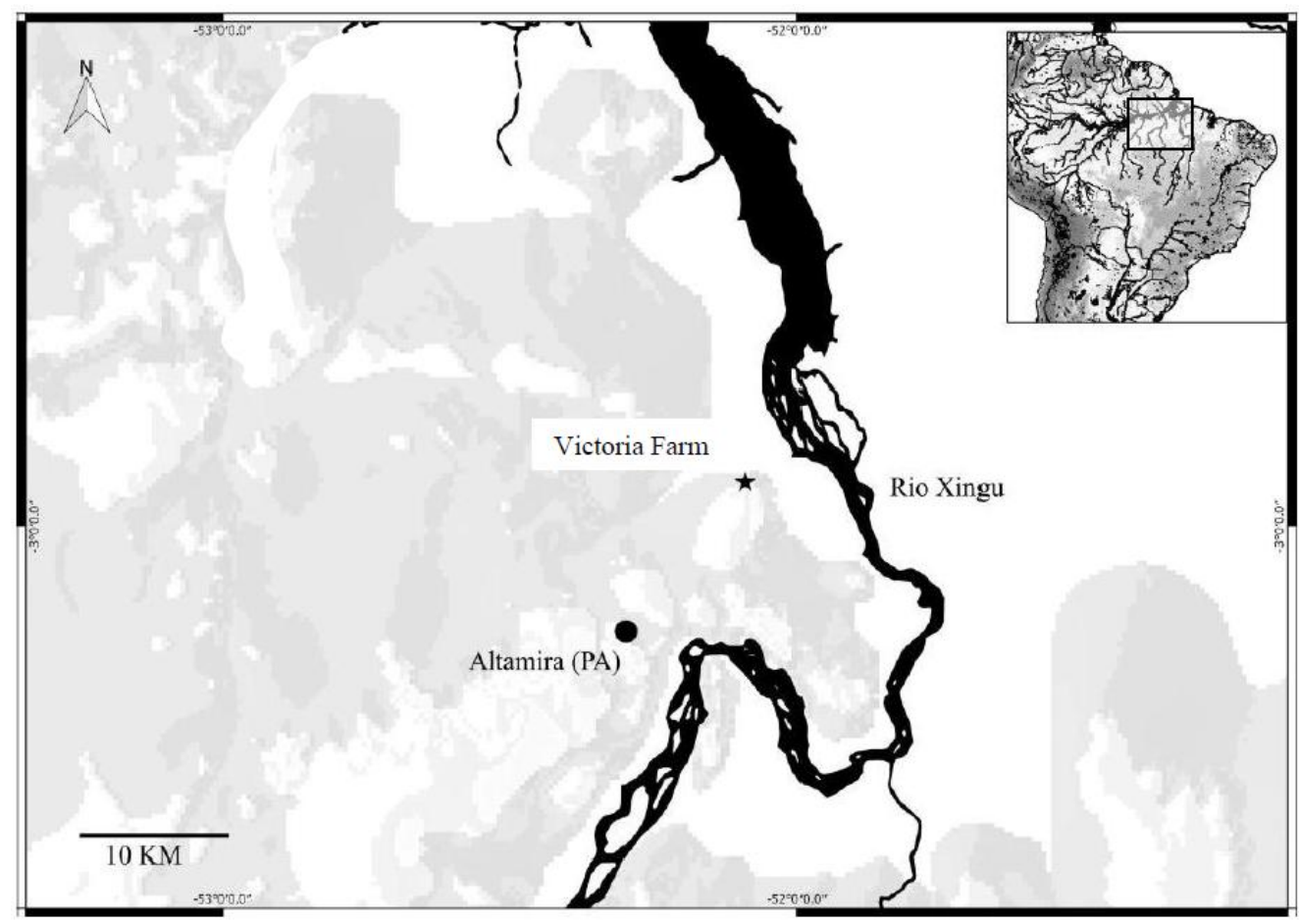

Figure4. Known distribution map for the new species. The star represents the type locality (Vitoria do Xingu) and the circle another point of record of the species (Altamira).

Cocrhanella sp. was registered in the north of the state of Pará, in the region of the Trombetas River [44]. However, [8] recognizes this record as the species Hyalinobatrachium mondolfii, also registered in the Xingu region [4]. After thorough morphological and molecular analyzes, the species registered in Xingu is described as a different one. Due to morphological similarities between anurans, many species are masked under a same name, the so called cryptic species [45]. The difficulty in the correct identification of species by taxonomy poses problems for the actions taken towards species conservation.

Even with the absence of vocalization, the new species is supported by the morphological differences presented above, as well as by molecular data. Despite the low support value separating the new species from its sister species ( $H$. mondolfii and $H$. munuzorum), Hyalinobatrachium muiraquitan presented a genetic distance from $5 \%$ and $4 \%$ respectively. Low resolution values in phylogenetic trees were found in Hyalinobatrachium [8], Pristimantis [46; 47], Lysapsus and Pseudis [48]. These results indicate that the inclusion of new genes is necessary for a better understanding of the phylogenetic relationships between species.

Hyalinobatrachium muiraquitan has been mistakenly called $H$. mondolfii due to their morphological similarities and the lack of specialists in the group in the Xingu region. Knowing that this is a region of the Amazon with great biological diversity, composing one of the eight areas of endemism [24], taxonomy studies should take priority. Knowledge of the biota of a region helps in making decisions regarding biodiversity conservation and, as such, taxonomy studies $[10 ; 39 ; 49]$, phylogenies $[8 ; 50$; 46] and inventories $[11 ; 39 ; 44]$ become relevant. Amphibians have been studied for some time as bioindicators of environment quality [51; 52]. It is well known that the species that inhabit a place and how they interact with the environment becomes relevant to preserve the biota.

The greatest diversity, with the largest number of species of the genus Hyalinobatrachium, is registered for Guiana shield, which includes countries such as Venezuela, Suriname, Guyana, French Guiana, Northern Brazil and a small portion of eastern Colombia $[8 ; 10 ; 11]$. The region presents a great chain of mountains called tepuis, with an altitudinal variation of $400-1200 \mathrm{~m}$ above sea level $[53 ; 54]$. These heterogeneous environmental conditions allowed the emergence of new species and endemism [11].

On the other hand, in the Amazon Basin the high richness of other taxa species such as birds has been associated with a process of specificity in-situ [55], repeated immigration into the Amazon from outside sources, and low levels of extinction within the basin [56]. The major Amazonian rivers often 
formed barriers to geographically replacing taxa, with closely related species or subspecies occupying opposing river banks $[57 ; 58]$. In this sense, Hyalinobatrachium muiraquitan can be endemic of the Xingu / Tapajós interfluvium, formed by two great tributaries of the Amazon River. The role of large Amazonian rivers as barriers to anuran species is well documented in the literature $[59 ; 60 ; 61 ; 62$; 63]. Thus, due to this geographical feature of the Amazon basin, the great rivers play a major role in the diversification of the biota by preventing gene flow between populations of opposite margins, leading to the emergence of new species $[24 ; 64 ; 65]$.

\section{CONClusion}

We conclude that Hyalinobatrachium muiraquitan can be easily differentiated from the species $H$. mondolfii by the truncated snout present in lateral view, the absence of nuptial excrescence and I finger disc white foot and peritoneum of the yellow gallbladder; from Hyalinobatrachium munozorum by present tarsal and ulnar fold, absence of basal webbing between the fingers I and II; from H. ruedai by the presence of melanophores in the body; from $H$. cappellei by its small yellow spots scattered around the body and discs of the fingers and yellow toes; from $H$. iaspidiense by its tiny yellow dots and black melanophores in the body.

\section{ACKNOWLEDGEMENTS}

We thank Mr. Darly, from the Municipal Secretariat of the Environment of Vitória do Xingu, State of Pará, Brazil for field logistics and Joyce Celerino de Carvalho for her assistance in the field during the collections.

\section{REFERENCES}

[1] Frost DR Amphibian Species of the World: an Online Reference. American Museum of Natural History, New York, USA. 2016. Version 6.0 (Date of access). Electronic Database accessible at http://research.amnh.org/herpetology/amphibia/index.html. Accssed 12 Jun 2016.

[2] Guayasamin JM, Castroviejo-Fisher, S, Trueb L, Rada M., Vila C. Phylogenetic systematics of Glassfrogs (Amphibia: Centrolenidae) and their sister taxon Allophryne ruthveni. Zootaxa, 2100, 1: 97.2009

[3] Sociedade Brasileira de Herpetologia - SBH. Lista de Anfíbios do Brasil 2016. Disponível emhttp://www.sbherpetologia.org.br/index.php/anfibios. Acessado em 30 de Novembro de 2016.

[4] Oliveira EA de, Hernández-Ruz EJ, Carvalho JC. Hyalinobatrachium mondolfii. Herp. review, 46 (3): 377: 378. 2015.

[5] Cisneros-Heredia DF, McDiarmid RW. Revision of the characters of Centrolenidae (Amphibia: Anura: Athesphatanura), with comments on its taxonomy and the description of new taxa of glassfrogs. Zootaxa, 1572, 1:82. 2007.

[6] Kok PJR, Castroviejo-Fisher S., Glassfrogs (Anura: Centrolenidae) of Kaieteur National Park, Guyana, with notes on the distribution and taxonomy of some species of the family in the Guiana Shield. Zootaxa, 1680, 25: 53. 2008.

[7] Barrio-Amorós CL, Castroviejo-Fisher S. Comments on the distribution, taxonomy and advertisement call of the Guyanan glass frog Hyalinobatrachium ignioculus (Anura: Centrolenidae). Salamandra, 44, 235: 240. 2008.

[8] Castroviejo-Fisher S, Moravec J, Aparicio J, Guerrero-Reinhard M, Calderón G. DNA taxonomy reveals two new species records of Hyalinobatrachium (Anura: Centrolenidae) for Bolivia. Zootaxa, 2798: 64: 68. 2011.

[9] Lynch JD, Duellman WE. A review of the Centrolenid frogs of Ecuador, with descriptions of new species. The University of Kansas Museum of Natural History Occasional Papers, 1973.

[10] Señaris JC, Ayarzagüena J. Revisión taxonómica de la familia Centrolenidae (Amphibia, Anura) en Venezuela. Sevilla: Publicaciones del Comité Español del Programa MaB y de la Red IberoMaB de la UNESCO Number 6. 2005.

[11] Cole CJ, Townsend CR, Reynolds RP, Mac Culloch RD and Lathrop A. Amphibians and reptiles of Guyana, South America: illustrated keys, annotated species accounts, and a biogeographic synopsis. Proceedings of the Biological Society of Washington, 125 (4), 317-578. 2013. 
[12] Lescure J and Marty C. Atlas des amphibians de Guyane. Muséum National d’Histoire Naturelle, Paris. 2000.

[13] Barrio-Amoros CL and Brewer-Carias C. Herpetological results of the 2002 expedition to Sarisarinama, a tepui in Venezuelan Guayana, with the description of five new species. Zootaxa, 1942, 3-68. 2008.

[14] Dayrat B. Towards integrative taxonomy. Biological Journal of the Linnean Society, 85, 407415. 2005.

[15] Padial JM, Castroviejo-Fisher S, Köhler J, Vila C, Chaparro JC and De la Riva I. Deciphering the products of evolution at the species level: the need for an integrative taxonomy. Zoologica Scripta, 38, 431-447. 2009.

[16] Padial JM, Miralles A, De la Riva I and Vences M. The integrative future of taxonomy. Frontiers in Zoology, 7, 16. 2010.

[17] Padial JM and De la Riva I. A response to recent proposals of Integrative taxonomy. Biological Journal of the Linnaean Society, 101, 747-756. 2010.

[18] Simpson GG. The species concept. Evolution, 5, 285-298. 1951.

[19] Simpson GG. Principles of Animal Taxonomy. Columbia University Press, New York. 1961.

[20] De Queiroz K. The general lineage concept of species: species criteria and the process of speciation. In: Endless Forms: Species and Speciation. Howard D.J., Berlocher S.H. New York: Oxford University Press. 1998.

[21] De Queiroz K. A unified concept of species and its consequences for the future of taxonomy. Proceedings of the California Academy of Sciences, 56, 196-215. (2005a.

[22] De Queiroz K. Species concepts and species delimitation. Systematic Biology, 56, 956-974. 2007.

[23] Silva MC da, Novaes FC and Oren DC. Differentiation of Xiphocolaptes (Dendrocolaptidae) across the river Xingu, Brazilian Amazonian: recognition of a new phylogenetic species and biogeography implications. Bulletin of The British Ornithologists' Club 122:185-194. 2001.

[24] Ribas CC, Aleixo A, Nogueira ACR, Miyaki CY and Cracraft J. A palaeobiogeographic model for biotic diversification within Amazonia over the past three million years. Proceedings of the Royal Society B: Biological Sciences 279: 681-689. 2012.

[25] Guayasamin JM, Castroviejo-Fisher S, Ayarzagüiena J, Trueb L and Vilà C. Phylogenetic relationships of glassfrogs (Centrolenidae) based on mitochondrial and nuclear genes. Molecular Phylogenetics and Evolution, 48, 574-595. 2008.

[26] Kok PJR and Kalamandeen M. Introduction to the taxonomy of the amphibians of Kaieteur National Park, Guyana. Abc Taxa 2008.

[27] Flores G. A new Centrolenella (Anura) from Ecuador, with comments on nuptial pads and prepollical spines in Centrolenella. Journal of Herpetology, 19, 313-320. 1985.

[28] Señaris JC and Ayarzagüena J. Una nueva especie de rana de cristal del género Hyalinobatrachium (Anura: Centrolenidae) del Delta del Río Orinoco, Venezuela. Revista de Biología Tropical, 49, 1083-1093. 2001.

[29] Wiens JJ And MR Servedio. Species delimitation in systematics: Inferring diagnostic differences between species. Proc. R. Soc. London Ser. B. 267, 631- 636. 2000.

[30] Maniatis T, Fritsch EF, Sambrook J. Molecular cloning: a laboratory Manual. New York: Cold spring Harbor Laboratory. 1982. http://www.cshlpress.com/pdf/sample/2013/MC4/MC4FM.pdf

[31] Palumbi SR, Martin A, Romano S, McMillan WO, Stice L, Grabowski G. "The Simple Fool's Guide to PCR, Version 2.0." Privately published document compiled by S. Palumbi, Dept. Zoology, Univ. Hawaii. 1991. http://palumbi.stanford.edu/SimpleFoolsMaster.pdf

[32] Thompson JD, Higgins DG, Gibson TJ. CLUSTAL W: improving the sensitivity of progressive multiple sequence alignment through sequence weighting, position specific gap penalties and weight matrix choice. Nucleic Acids Research, 22, 4673-4680. 1996 http://www.ncbi.nlm.nih. gov/ pmc/articles/PMC308517/pdf/nar00046-0131.pdf

[33] Hall TA. BioEdit: a user-friendly biological sequence alignment editor and analysis program for Windows 95/98/NT. Nucleic Acids Symposium Series, 41, 95-98. 1999. http://brownlab.mbio. ncsu.edu/ JWB/papers/1999Hall1.pdf 
[34] Darriba D, Taboada GL, Doallo R, Posada D. "jModelTest 2: more models, new heuristics and parallel computing". Nature Methods 9(8), 772. 2012. DOI:10.1038/nmeth.2109

[35] Jobb G. TREEFINDER version of March of 2011. 2008. Munich, Germany. Distributed by the author at www.treefinder.de. (Accessed 30 of June 2014).

[36] Tamura K, Dudley J, Nei M, Kumar S. MEGA 6.0: Molecular Evolutionary Genetics Analysis (MEGA) software version 4.0. Molecular Biology and Evolution, 24, 1596-1599. 2007. http://www.megasoftware.net/pdfs/TamuraKumar07.pdf

[37] Corander J, Sirén J, and Arjas E. Bayesian Spatial modeling of genetic Population Structure. Computational Statistics 23: 111-129. 2008.

[38] Ruiz-Carranza PM, Lynch JD. Ranas Centrolenidae de Colombia I: propuesta de una nueva clasificación genérica. Lozania 57, 1-30. 1991a.

[39] Ruiz-Carranza PM, Lynch JD. Ranas Centrolenidae de Colombia XI: nuevas especies de ranas cristal del género Hyalinobatrachium. Rev. Acad. Colombiana Cienc. Exact. Fís. Natur. 85, 571586. 1998.

[40] Vences M, Thomas M, Meijden A. van der, Chiari Y and Vieites DR. Comparative performance of the 16S rRNA gene in DNA barcoding of amphibians. Frontiers in Zoology 2, 1-12. 2005.

[41] Fouquet A, Gilles A, Vences M, Marty C, Blanc M and Gemmell NJ. Underestimation of species richness in neotropical frogs revealed by mtDNA analyses. PLoS ONE, 10, 1-10. 2007b.

[42] Gehara M, Crawford AJ, Orrico VGDM, Rodríguez A, Lötters S, Fouquet A, Barrientos LS, Brusquetti F, De la Riva I, Ernst R, Urrutia GG, Glaw F, Guayasamin JM, Hölting M, Jansen M, Kok PJR, Kwet A, Lingnau R, Lyra M, Moravec J, Pombal JP, Rojas-Runjaic FJM, Schulze A, Señaris JC, Solé M, Rodrigues MT, Twomey E, Haddad CFB, Vences M and Köhler J. High Levels of Diversity Uncovered in a Widespread Nominal Taxon: Continental Phylogeography of the Neotropical Tree Frog Dendropsophus minutus. PLoS ONE, 9 (9), 1-12. 2014.

[43] Fouquet A, Santana Cassini C, Fernando Baptista Haddad C, Pech N, Trefaut Rodrigues M. Species delimitation, patterns of diversification and historical biogeography of the Neotropical frog genus Adenomera (Anura, Leptodactylidae). Journal of Biogeography. 41(5):855-870. 2014.

[44] Avila-Pires TCS, Hoogmoed MS, Rocha WA da. Notes on the Vertebrates of northern Pará, Brazil: a forgotten part of the Guianan Region, I. Herpetofauna. Boletim do Museu Paraense Emílio Goeldi 5, 13-112. 2010.

[45] Pfenninger $M$ and Schwenk K. Cryptic animal species are homogeneously distributed among taxa and biogeographical regions. BMC evolutionary biology 7, 121. 2007.

[46] Padial JM, Grant $T$ and Frost DR. Molecular systematics of terraranas (Anura: Brachycephaloidea) with an assessment of the effects of alignment and optimality criteria. Zootaxa 3825, 1-132. 2014.

[47] Shepack A, May R. V, Ttito A e Catenazzi1 A. A new species of Pristimantis (Amphibia, Anura, Craugastoridae) from the foothills of the Andes in Manu National Park, southeastern Peru . Zookeys 594:143 - 164. 2016.

[48] Aguiar-Jr O, Bacci Jr M, Lima A P, Rossa-Feres D C, Haddad C FB AND Recco-Pimentel SM. Phylogenetic relationships of Pseudis and Lysapsus (Anura, Hylidae,Hylinae) inferred from mitochondrial and nuclear gene sequences. Cladistics 23, 1-9 (2007).

[49] Castroviejo-Fisher S, Ayarzagüena J. and Vilà C. A new species of Hyalinobatrachium (Centrolenidae: Anura) from Serranía de Perijá, Venezuela. Zootaxa 1441: 51-62. 2007.

[50] Guayasamin JM, Castroviejo-Fisher S, Trueb L, Ayarzagüena J, Rada M and Vilà C. Phylogenetic systematics of Glassfrogs (Amphibia: Centrolenidae) and their sister taxon Allophryne ruthveni. Zootaxa, 2100, 1-97. 2009.

[51] Machado RA, Bernarde PS, Morato SAA and Anjos L dos. Análise comparada da riqueza de anuros entre duas áreas com diferentes estados de conservação no município de Londrina, Paraná, Brasil (Amphibia, Anura). Revista Brasileira de Zoologia 16 (4): 997 - 1004. 1999.

[52] Toledo LF. Anfíbios como bioindicadores. In: Bioindicadores da qualidade ambiental (S. Neumann-Leitão and S. El-Dier, org.). Instituto Brasileiro Pró-Cidadania, Recife, p.196-208. 2009. 
[53] Kok PJR, MacCulloch RD, Means DB, Roelants K, Van Bocxlaer I and Bossuyt F. Low genetic diversity in tepui summit vertebrates. Current Biology 22(15): 589-590. 2012. + supplementary information. http://dx.doi.org/10.1016/j.cub.2012.06.034

[54] Kok PJR. Islands in the Sky: Species Diversity, Evolutionary History, and Patterns of Endemism of the Pantepui Herpetofauna. PhD thesis, Leiden University, The Netherlands. 2013.

[55] Weir JT, Faccio MS, Pulido- Santacruz P, Barrera-Guzma'n AO, Aleixo A. Hybridization in headwater regions, and the role of rivers as drivers of speciation in Amazonian birds. Evolution 69,7, 1823 - 1834. 2015.

[56] Fjeldsa J. Geographical patterns for relict and young species of birds in Africa and SouthAmerica and implications for conservation priorities. Biod. Cons. 3: 207- 226. 1994.

[57] Bates HW. The Naturalist on the River Amazons. (1863).

[58] Wallace AR. On the monkeys of the Amazon. Zool. Soci. of Lond. 20: 107- 110. 1849.

[59] Funk WC, Caldwell JP, Peden CE, Padial JM, R iva I De La and Cannatella DC. Tests of biogeographic hypotheses for diversification in the Amazonian forest frog, Physalaemus petersi. Mol. Phylo- genet. Evol. 44, 825-837. 2007.

[60] Fouquet A, Ledoux JB, Dubut V, Noonan BP and Scotti I. The interplay of dispersal limitation, rivers, and historical events shapes the genetic structure of an Amazonian frog. Biological Journal of the Linnean Society 106, 356-373. 2012.

[61] Kaefer IL, Tsuji-Nishikido BM and Lima AP. Beyond the river: Underlying determinants of population acoustic signal variability in Amazonian direct-developing Allobates (Anura: Dendrobatoidea). Acta Ethologica 15, 187-194. 2012.

[62] Kaefer IL, Tsuji-Nishikido BM, Mota EP, Farias IP and Lima AP. The Early Stages of Speciation in Amazonian Forest Frogs: Phenotypic Conservatism Despite Strong Genetic Structure. Evolutionary Biology 40, 228-245. 2013.

[63] Simões PI, Stow A, Hödl W, Amézquita A, Farias IP and Lima AP. The value of including intraspecific measures of biodiversity in environmental impact surveys is highlighted by the Amazonian brilliant-thighed frog (Allobates femoralis). Research Article, 7, 811-828. 2014.

[64] Hayes FE and Sewlal JAN. The Amazon River as a dispersal barrier to passerine birds: effects of river width, habitat and taxonomy. Journal of Biogeography, 31, 1809-1818. 2004.

[65] Zeisset I and Beebee T. Amphibian phylogeography: a model for understanding historical aspects of species distributions. Heredity 101, 109-119. 2008.

\section{ADDITIONAL INFORMATION 1}

Measurements of all specimens of Hyalinobatrachium muiraquitan sp. nov. used in this study.

\begin{tabular}{|l|l|l|l|l|l|l|l|l|l|l|l|l|}
\hline Indivíduo & Sexo & SVL & HL & HW & IOD & EL & EW & ES & FIII & FEL & TL & FL \\
\hline LZA 841 & M & 19.2 & 8.8 & 7.6 & 1.5 & 1.8 & 0.9 & 3.0 & 3.5 & 10.3 & 9.9 & 8.0 \\
\hline LZA 844 & F & 21.8 & 6.4 & 7.6 & 1.7 & 2.1 & 1.5 & 2.9 & 3.4 & 11.2 & 11.2 & 9.1 \\
\hline LZA 843 & F & 20.0 & 6.6 & 8.1 & 1.9 & 2.4 & 1.7 & 3.0 & 3.7 & 10.8 & 10.6 & 8.9 \\
\hline LZA 842 & M & 19.6 & 6.2 & 7.5 & 1.6 & 2.4 & 1.8 & 3.0 & 3.2 & 10.7 & 10 & 8.7 \\
\hline
\end{tabular}

\section{ADDITIONAL INFORMATION 2}

List of specimens used for qualitative morphology based on the literature works cited in this paper.

Hyalinobatrachium mondolfii, Estado Delta Amacuro, Venezuela, MHNLS 12710;

Hyalinobatrachium ruedai, Miraflores, Colômbia, ICN 40409;

Hyalinobatrachium iaspidiense, EBD 28803 (holotype);

Hyalinobatrachium munozorum, KU 155497;

Hyalinobatrachium cappellei, RMNH 37850;

Hyalinobatrachium orientale, Monagas, Cueva del Guácharo, Venezuela, MHNLS 13353; Río Pajaral, afluente del Río Caripe, MHNLS 14750-14752, MHNLS 13354.

Hyalinobatrachium fleischmanni, San Jose, Provincia, Costa Rica, SMF 3760, (holotype);

Hyalinobatrachium ibama, Gambita, Colômbia, ICN 12602;

Hyalinobatrachium esmeralda, Pajarito, Colômbia, ICN 9598. 